\title{
Genetic Divergence in Sweet Cassava Cultivars Using Morphological Agronomic Traits and RAPD Molecular Markers
}

\author{
Fabrício Rimoldi ${ }^{1}$, Pedro Soares Vidigal Filho ${ }^{1 *}$, Marcus Vinícius Kvitschal ${ }^{2}$, Maria Celeste \\ Gonçalves-Vidigal ${ }^{1}$, Alberto José Prioli ${ }^{3}$, Sônia Maria Alves Pinto Prioli ${ }^{3}$ and Tiago Ribeiro \\ da Costa ${ }^{1}$ \\ ${ }^{I}$ Departamento de Agronomia; Universidade Estadual de Maringá; Av. Colombo, 5790; 87020-570; Maringá - PR - \\ Brasil. ${ }^{2}$ Melhoramento Genético Vegetal; Empresa de Pesquisa Agropecuária e Extensão Rural de Santa Catarina; \\ Rua Abílio Franco, 1500, C. P.: 591; 89500-000; Caçador - SC - Brasil. ${ }^{3}$ Departamento de Biologia; Universidade \\ Estadual de Maringá; Av. Colombo, 5790; 87020-570; Maringá - PR - Brasil
}

\begin{abstract}
In this work the genetic divergence among 14 sweet cassava cultivars was estimated by their morphological agronomic traits and RAPD molecular markers. The Tocher cluster analysis and the Nearest Neighbor Method were applied. The most dissimilar cultivars were Pão and Guaíra, Fécula Branca and Pão, and Pão and Caipira, while the most similar cultivar were the Fécula Branca and Branca 1, Branca 3 and Branca 1, and Guaíra and Branca 1. The Jaccard's coefficient showed that the most similar cultivars were Guaira and Quarenta Quilos, while the most dissimilar were Branca 3 and Amarela da Rama Cinza. The divergence analysis indicated that promising crosses could be made between the Branca 3 cultivar and the Pão, Amarela 1, Fécula Branca and Amarela 2 cultivars for the high genetic divergence, favorable agronomic and culinary traits, and disease resistance on the part of at least one of the parents involved in the cross.
\end{abstract}

Key words: Genetic diversity; Manihot esculenta; Multivariate analysis.

\section{INTRODUCTION}

In the Manihot esculenta Crantz species, there are some common problems with the nomenclature and characterization of cultivars. These problems mainly pertain to sweet cassava, due to its cultivation by smallholders that generally select and distribute the cultivars by themselves (Zacharias et al., 2004). Therefore, sometimes the same genotype can possess different names or different genotypes may have the same name
(Emperaire and Peroni, 2007). Since this potential confusion limits the application of genetic variability to improve the crop, either for consumption or for use in breeding programs, a careful characterization is necessary to define the, existing genetic variability (Fukuda and Guevara, 1998; Kizito et al., 2007). The characterization by morphological descriptors is understood as the overall phenotypic characteristic that permits the easy identification and differentiation of accessions from a germplasm bank in the field.

*Author for correspondence: psvfilho@uem.br 
Generally, these descriptors have high herdability, suggesting that they are expressed even in different environments (Fukuda and Guevara, 1998). However, the cultivar characterization based only on morphological descriptors can also be frequently subject to errors that result from variations in environmental conditions, especially if the cultivars under study are of similar origin, or if some agronomic characteristics are not specific (Carvalho and Schaal, 2001; Collard et al., 2005).

In contrast, the recent advances in molecular biology techniques have provided useful tools for genetic studies on several plant species. The use of molecular markers may permit, among other aspects, the detection of more expressive genetic differences among the closest genotypes when compared with the use of morphological agronomic descriptors (Collard et al., 2005). Thus, the characterization of accessions kept in the germplasm banks can be more detailed and reliable if molecular markers are associated with the morphological agronomic traits. This considerably reduces the degree of difficulty in detecting the differences among genetically close individuals and further enables the identification of duplicates kept in the germplasm banks (Chavarriaga-Aguirre et al., 1999; Zacharias et al., 2004; Kizito et al. 2007; Zannou et al., 2009).

The objective of the present study was to assess the genetic divergence among the traditional sweet cassava cultivars collected in the northern, western, and northwestern regions of Paraná State using morphological agronomic traits and RAPD molecular markers.

\section{MATERIAL AND METHODS}

The sweet cassava assessment experiments were set up in the municipality of Maringá (Iguatemi Experimental Farm - UEM) in the northwestern region of Paraná state, which has a wet mesothermic climate with hot summers and rains in the summer and fall rains. The predominant soil in the experimental area was dystrophic Red Latossol, and chemical analysis revealed the following characteristics: $\mathrm{pH}\left(\mathrm{H}_{2} \mathrm{O}\right): 5.6 ; \mathrm{H}^{+}+\mathrm{Al}^{3+}$ $3.68 \mathrm{cmol}_{\mathrm{c}} \cdot \mathrm{dm}^{-3} ; \mathrm{Al}^{3+}: 0.00 \mathrm{cmol}_{\mathrm{c}} \cdot \mathrm{dm}^{-3} ; \mathrm{Ca}^{2+}+$ $\mathrm{Mg}^{2+}: 4.47 \mathrm{cmol}_{\mathrm{c}} \cdot \mathrm{dm}^{-3} ; \mathrm{Ca}^{2+}: 3.25 \mathrm{cmol}_{\mathrm{c}} \cdot \mathrm{dm}^{-3} ; \mathrm{K}^{+}$: $0.23 \mathrm{cmol}_{\mathrm{c}} \cdot \mathrm{dm}^{-3}$; and P: $6.00 \mathrm{mg} \cdot \mathrm{dm}^{-3}$. A total of 14 sweet cassava cultivars, which were collected from the smallholders in the northern, northwestern, and western regions of Paraná state
(Rimoldi et al., 2006), were assessed in a completely randomized plot design with four replications (Cruz and Carneiro, 2006).

The soil was prepared by the minimum preparation system that used only a decompacting plow. In both the assessment periods, planting took place during the first two weeks of October by manually opening hill plots, and the cuttings were placed horizontally in holes that were approximately 0.10 $m$ deep (Sagrilo et al., 2006). Standard crop treatments and fertilization for cassava crop were applied. $\quad$ Sinerge $^{\circledR}$ herbicide (triazin + isoxazolidinon) was used to control the weeds and was applied during the pre-emergence stage at a dose of $4 \mathrm{~L}^{\mathrm{L}} \mathrm{ha}^{-1}$ of the commercial product. The experimental units measured $8.0 \mathrm{~m}$ long by $4.0 \mathrm{~m}$ wide with four rows of plants spaced at $1.0 \mathrm{~m}$ intervals with $0.80 \mathrm{~m}$ between-plant spacing (Kvitschal et al., 2009). The useful area of the plots consisted of two central rows, and $0.80 \mathrm{~m}$ from the ends of each row was eliminated.

The plants were harvested nine months after plant emergence, and the following morphological agronomic traits were assessed: a) plant height (PH) for ten plants from each plot, which was given in meter and obtained by measuring the distance from soil level to shoot extremity with a tape measure marked in millimeters; b) height of the first branching (HB) for all the plants in the useful area in the plot, which was given in $\mathrm{m}$ and obtained by measuring from soil level to the point of the first branching; c) internodal distance (ID) for ten plants in the useful area of the plot, which was obtained by measuring the distance between the internodes; d) final plant to stand (PS), which was obtained by counting the number of plants in the useful area of the plot; e) stem diameter (SD) for ten plants per plot, which was expressed in $\mathrm{cm}$ and obtained by measuring the stem diameter of the plant at the height of $0.10 \mathrm{~m}$ from the soil; f) tuberous root diameter (RD) for twelve tuberous roots that were collected randomly from each plot, which was expressed in $\mathrm{cm}$ and obtained by measuring the root with a caliper rule; g) number of tuberous roots per plant (NR) for each plant in the useful area of the plot, which was obtained by counting the tuberous roots from each plant; h) tuberous root length (RL) for twenty tuberous roots from the useful area of each plot, which was expressed in $\mathrm{cm}$ and obtained randomly by measuring the length of each tuber using a measuring tape; i) canopy production $(\mathrm{CP})$ for all the plants in the useful area of each plot, which 
was expressed in tha ${ }^{-1}$ and obtained by weighing the existing canopy that began at $0.10 \mathrm{~m}$ above soil level; $j$ ) tuberous root yield (RY) from all plants that were harvested from the useful area of the plot, which was expressed in $\mathrm{t} \mathrm{ha}^{-1}$ and obtained by weighing the tuberous roots; $\mathrm{k}$ ) tuberous root cooking time (CT), which was expressed in min using the adapted Mattson apparatus (Mattson, 1946); and 1) tuberous root dry matter percentage (DM) from a $3.0 \mathrm{~kg}$ tuberous root sample that was collected from each experimental plot, which was determined by the hydrostatic balance method (Grosmann and Freitas, 1950). The cyanide content (HCN) in the fresh storage root tissue, the cocking time, and the reaction to the bacterial blight of each cultivar evaluated can be found in Rimoldi et al. (2006).

Plant tissue was also collected from the young leaves of each cultivar at this time for the analysis of molecular markers. Preliminary assessments of the 14 cultivars showed that every plant of each cultivar that was tested produced identical genotyped, which reflected a reliable degree of repeatability. Therefore, two individuals from each cultivar were assessed in the molecular analysis. DNA was extracted using the Doyle and Doyle (1990) protocol, with minor modifications. Five or six healthy young leaves were removed from each of the two representative plants from the 14 cultivars. The leaves were duly identified, placed in plastic bags, and taken immediately to the laboratory where they were squashed in liquid nitrogen.

A sample of approximately $150 \mathrm{mg}$ of the squashed leaves was then transferred to an Eppendorf tube. After the addition of $700 \mu \mathrm{l}$ of extraction buffer, the tubes were shaken and placed in a water bath at $60^{\circ} \mathrm{C}$ for $30 \mathrm{~min}$. After cooling, the tubes were centrifuged for about 10 min, and $700 \mu l$ of the supernatant were collected. An equal volume $(700 \mu \mathrm{l})$ of Sevag (isoamylic Chloroform:Alcohol - 24:1) was added, and the samples were manually shaken for $10 \mathrm{~min}$. After another 10-minute centrifugation, $500 \mu \mathrm{l}$ of the supernatant were removed, and $50 \mu \mathrm{l}$ of $10 \%$ CTAB and $550 \mu \mathrm{l}$ of Sevag were added. The samples were shaken and centrifuged for $10 \mathrm{~min}$, and $400 \mu \mathrm{l}$ of the supernatant were then collected. An equal volume of precipitation buffer $(400 \mu \mathrm{l})$ was added, and the samples were incubated at room temperature for $15 \mathrm{~min}$. The samples were centrifuged for $5 \mathrm{~min}$, the supernatant was discarded, and $400 \mu \mathrm{l}$ of high salt TE were added.
The samples were then incubated in a water bath at $65^{\circ} \mathrm{C}$ for $5 \mathrm{~min}$. The tubes were shaken, $800 \mu \mathrm{l}$ of chilled isopropyl alcohol were added, and the samples were placed in a freezer $\left(-8^{\circ} \mathrm{C}\right)$ for $12 \mathrm{~h}$.

The DNA was washed the following morning. The samples were centrifuged, and the supernatant was discarded. To remove the salts, $700 \mu \mathrm{l}$ of $70 \%$ ethanol was added. The sample was again centrifuged for $10 \mathrm{~min}$, the supernatant was discarded, and the samples were dried at room temperature. The DNA was re-suspended in $30 \mu 1$ RNAse/TE. The DNA was electrophoresed in a $0.8 \%$ agarose gel and quantified by comparing the band brightness to three different concentrations of lambda DNA. Based upon previously established standards for RAPD reactions, the concentration of each sample was set at $10 \mathrm{ng} . \mathrm{\mu l}^{-1}$.

For PCR, the following arbitrary primers were selected: OPJ 07, OPZ 04, OPK 14, OPJ 09, OPI 06, OPI 07, OPL 07, OPZ 09, OPY 16, OPJ 08, OPK 04, OPM 10, and OPM 05 (Operon Technologies, Alameda, CA, USA). The mixture for the amplification reactions (MIX) contained 4 $\mu \mathrm{M}$ primers, Tris- $\mathrm{KCl}$ Buffer $(20 \mathrm{mM}$ Tris- $\mathrm{HCl}$, pH 8.4 and $50 \mathrm{mM} \mathrm{KCl)} 50 \mathrm{mM} \mathrm{MgCl} 2,50 \mathrm{mM}$ dNTP, $1 \mathrm{U}$ Taq $(2.5 \mathrm{mM})$ Polymerase, 3 to $5 \mathrm{ng}$ of DNA and enough Milli-Q water to bring the mixture to a total volume of $13 \mu \mathrm{l}$.

The PCR included a negative control for each primer that consisted of the MIX without DNA. The DNA fragments were amplified in a Perkin Elmer DNA Thermocycler, following the protocol of Williams et al. (1990). Briefly, each amplification cycle consisted of a denaturation step at $94^{\circ} \mathrm{C}$ for $15 \mathrm{~s}$, a primer annealing step at $35^{\circ} \mathrm{C}$ for $30 \mathrm{~s}$ and an elongation step at $72^{\circ} \mathrm{C}$ for $60 \mathrm{~s}$. At the end of 40 cycles, an additional elongation step was carried out at $72^{\circ} \mathrm{C}$ for $7 \mathrm{~min}$. The amplification products were separated on a $1.4 \%$ agarose gel diluted in TBE buffer with $0.02 \%$ ethidium bromide, which was run at 3 V.cm ${ }^{-1}$ until the DNA had migrated at least $10 \mathrm{~cm}$. The bands that were obtained were visualized under ultraviolet light and photographed with a digital image capturing system. Only those DNA bands that were clearly visible were selected.

The genetic divergence study among the sweet cassava cultivars was determined by multivariate analyses of the agronomic and morphological traits using both the Tocher cluster analysis, which was based on the Mahalanobis generalized distance, and the nearest neighbor analysis (Gonçalves-Vidigal et al., 1997). The genetic 
divergence among the sweet cassava cultivars was assessed by constructing a binary data matrix that referenced the amplified polymorphic fragments of the RAPD molecular markers.

The similarity among the cultivars was estimated by the Jaccard's coefficient. The complement of the Jaccard's coefficient was used to analyze the clustering, and, thus, estimate the dissimilarity between the cultivars. The cultivars were then clustered by the nearest neighbor method and dispersed in a bidimensional graph, based upon the binary dissimilarity matrix that uses the computer resources of the GENES program (Cruz, 2006).

\section{RESULTS AND DISCUSSION}

The genetic divergence averages among the sweet cassava cultivars were based upon the Mahalanobis generalized distance, which was estimated from morpho-agronomic traits (Table 1). The greatest genetic distances were observed among the Pão and Guaíra, the Fécula Branca and Pão, and the Pão and Caipira cultivars, which had $D^{2}{ }_{i i}$ ' values with magnitudes of $262.856,253.999$, and 218.487 , respectively. The cultivar pairs that showed the smallest genetic distance values, and thus that were considered to be the most similar cultivars, were the Fécula Branca and Branca 1, the Branca 3 and Branca 1, and the Guaíra and Branca 1 cultivars, with values of 17.04, 19.85 and 22.99, respectively (Table 1). The Pão cultivar appeared the most frequently in combinations involving the more divergent cultivars, while the Branca 1 cultivar appeared the most frequently in combinations involving the closest cultivars.

The Tocher cluster analysis, using the Mahalanobis generalized distance $\left(D^{2}{ }_{i i}{ }^{\prime}\right)$ as a measure of dissimilarity, created six groups of cultivars: Group I included the Branca 1, Fécula Branca, Branca 3, Guaíra, Amarela 1, and Branca cultivars and had a representativeness of $42.85 \%$; Groups II, which included the Pão and Amarela 2 cultivars, III, which included the Amarela da Rama Branca and Branca de Maringá cultivars, and IV, which included the Caipira and Quarenta Quilos cultivars, each with a representativeness of 14.29\%; and Groups V, which included the Amarela de São Domingos cultivar, and VI, which included the Amarela da Rama Cinza cultivar, with a representativeness of $7.14 \%$ each.

Table 1 - Dissimilarity matrix estimated by the Mahalanobis generalized distance $\left(D^{2}{ }_{i i}\right)$ among the sweet cassava cultivars based on 12 morphological agronomic traits.

\begin{tabular}{|c|c|c|c|c|c|c|c|c|c|c|c|c|c|}
\hline & Caip. & Br.1 & Q.Q. & Gua. & A.R.Br. & A.R.C. & Br.M. & $\mathrm{Br} .2$ & A.S.D. & $\mathrm{Br} .3$ & Pão & Am. 1 & F.Br. \\
\hline Caip. & 0.000 & & & & & & & & & & & & \\
\hline Br.1 & 33.775 & 0.000 & & & & & & & & & & & \\
\hline Q.Q. & 43.581 & 77.074 & 0.000 & & & & & & & & & & \\
\hline Gua. & 48.621 & 22.994 & 108.728 & 0.000 & & & & & & & & & \\
\hline A.R.Br. & 171.402 & 91.778 & 155.957 & 125.566 & 0.000 & & & & & & & & \\
\hline A.R.C. & 150.017 & 89.358 & 97.542 & 151.027 & 41.623 & 0.000 & & & & & & & \\
\hline Br.M. & 107.980 & 62.923 & 133.307 & 91.584 & 37.636 & 59.485 & 0.000 & & & & & & \\
\hline $\mathrm{Br} .2$ & 70.158 & 33.872 & 74.865 & 27.930 & 78.589 & 84.506 & 82.624 & 0.000 & & & & & \\
\hline A.S.D. & 81.112 & 43.486 & 91.226 & 62.377 & 92.272 & 86.694 & 71.176 & 64.381 & 0.000 & & & & \\
\hline Br.3 & 46.223 & 19.847 & 59.738 & 45.833 & 75.397 & 61.506 & 58.578 & 31.704 & 31.447 & 0.000 & & & \\
\hline Pão & 218.487 & 187.700 & 119.291 & 262.856 & 96.060 & 49.022 & 124.477 & 187.635 & 177.933 & 152.226 & 0.000 & & \\
\hline Am. 1 & 52.194 & 26.796 & 61.405 & 32.629 & 118.857 & 100.843 & 107.966 & 41.921 & 41.964 & 30.951 & 170.529 & 0.000 & \\
\hline F.Br. & 41.640 & 17.038 & 100.395 & 29.558 & 127.087 & 137.059 & 83.339 & 52.200 & 39.606 & 23.207 & 253.999 & 45.748 & 0.000 \\
\hline Am. 2 & 145.845 & 127.541 & 68.122 & 198.405 & 104.808 & 45.706 & 118.514 & 143.396 & 109.870 & 97.904 & 36.559 & 107.218 & 181.753 \\
\hline
\end{tabular}


The dendrogram representing the genetic divergence among the sweet cassava cultivars, which was obtained by the nearest neighbor method and used $D_{i i}^{2}$ as dissimilarity measurement, created two large groups (Fig. 1). Group I was divided into two subgroups, with a similarity of $43.58 \%$. The first subgroup was formed by the Branca 1, Fécula Branca, Branca 3, Amarela 1, Guaíra, Branca 2, and Amarela de São Domingos cultivars, while the second group was formed by the Caipira and Quarenta Quilos cultivars. Group II was also divided into two subgroups with a similarity of $37.60 \%$. The first subgroup was formed by the Amarela da Rama Branca and Branca de Maringá cultivars. The second subgroup was formed by the Amarela da Rama Cinza, Pão and Amarela 2 cultivars, which highlighted the proximity between the Pão and Amarela 2 cultivars $(36.56 \%)$.

The Pão, Fécula Branca, and Caipira cultivars presented a good tuberous root yield, a low cyanide content, a fast-to-moderate tuberous root cooking time, a high dry matter content, and a low incidence of cassava bacterial blight (Rimoldi et al., 2006). This collection of traits indicated that these three cultivars could be promising parents for sweet cassava genetic breeding programs (Coimbra et al., 1998). Although the Guaíra cultivar presented favorable agronomic traits, it also had a high susceptibility to cassava bacterial blight and superelongation (Rimoldi et al., 2006).

The Amarela 2 cultivar, which presented satisfactory agronomic and culinary characteristics, should be another good parent choice for programs involving hybridizations, because it also was resistant to cassava bacterial blight and superelongation while presenting high genetic divergence from many of the studied cultivars (Table 1).

In contrast, crosses involving the Amarela 2 and the Quarenta Quilos, Amarela da Rama Cinza and Pão cultivars were not indicated, given the genetic proximity observed between these cultivars (Fig. 1 ), which would result in a low heterogenetic effect in the resulting progenies.

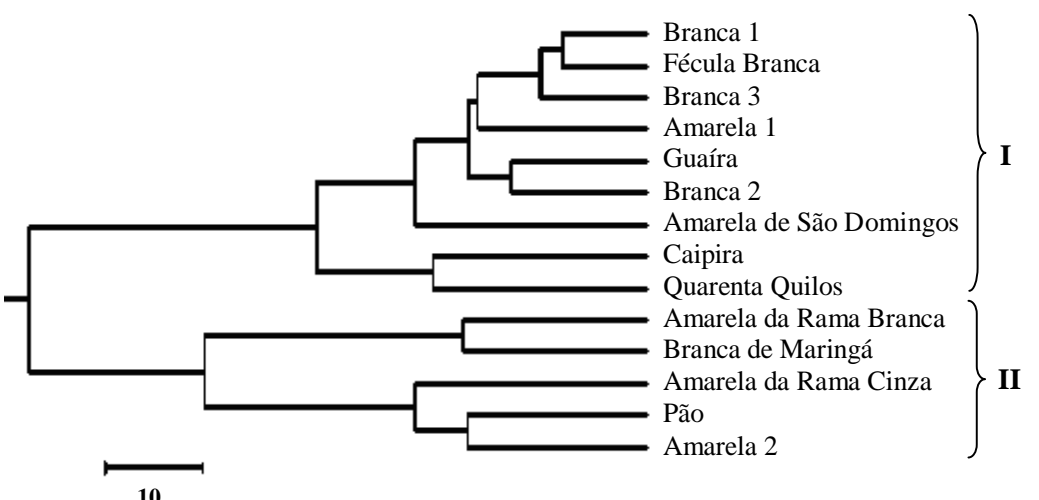

Figure 1 - Dendrogram representative of the genetic divergence, based on morphological agronomic traits, among the 14 cultivars, obtained by the nearest neighbor analysis method using $D_{i i}^{2}$, as dissimilarity measurement.

With respect to the molecular analyses, the 13 primers generated a total of 119 amplified bands, with an average of 9.15 bands per primer (Table 2). The amplified fragment sizes ranged from 150 to 2,000 base pairs. The selected primers displayed an $83.19 \%$ polymorphism rate among the 14 cultivars, and 99 bands, at an average of 7.61 bands per primer, produced a different pattern for at least two separate cultivars. These results demonstrated that there was a wide range of genetic variability among all the 14 cultivars, which was in line with previously reported results (Farias et al., 1997; Chavarriaga-Aguirre et al., 1999; Zacharias et al., 2004; Peroni et al., 2007; Kizito et al., 2007; Siqueira et al., 2009).

The high degree of polymorphism that was observed in the 14 sweet cassava cultivars was expected, given their heterogeneous nature. There have been several factors that have increased the heterogeneity of the Brazilian cultivars: a) the sweet cassava originated in Brazil (Allen, 1994); b) the particular cultivars from Paraná State were 
obtained from smallholders; and c) farmers mainly propagated the cassava vegetatively through stem cuttings that were obtained from mature plants in their fields. Occasionally, these small-scale farmers would also incorporate cuttings, which have been obtained from volunteer seedlings produced by sexual reproduction, into their varieties (Emperaire and Peroni, 2007; Kizito et al. 2007).

Table 2 - Primers used, base sequences, number of polymorphic bands obtained and size of the amplified RAPD fragments of 14 traditional sweet cassava cultivars.

\begin{tabular}{lcccc}
\hline Primer & Sequence $\left(\mathbf{5}^{\prime} \rightarrow \mathbf{3}^{\prime}\right)$ & Amplified bands & Polymorphic bands & Length $(\mathbf{p b})$ \\
\hline OPI 06 & AAGGCGGCAG & 12 & 12 & 350 to 1,400 \\
OPI 07 & CAGCGACAAG & 13 & 7 & 150 to 1,800 \\
OPJ 07 & CCTCTCGACA & 12 & 11 & 450 to 2,000 \\
OPJ 08 & CATACCGTGG & 7 & 6 & 500 to 1,500 \\
OPJ 09 & TGAGCCTCAC & 5 & 5 & 500 to 1,800 \\
OPK 04 & CCGCCCAAAC & 13 & 11 & 380 to 1,800 \\
OPK 14 & CCCGCTACAC & 10 & 7 & 450 to 2,000 \\
OPL 07 & AGGCGGGAAC & 6 & 6 & 300 to 1,400 \\
OPM 10 & TCTGGCGCAC & 7 & 5 & 300 to 1,800 \\
OPN 05 & ACTGAACGCC & 8 & 8 & 450 to 1,700 \\
OPY 16 & GGGCCAATGT & 9 & 8 & 450 to 2,000 \\
OPZ 04 & AGGCTGTGCT & 8 & 5 & 450 to 1,200 \\
OPZ 09 & CACCCCAGTC & 9 & 8 & 600 to 1,900 \\
\hline
\end{tabular}

An example of a polymorphic band pattern, using the OPK 14 primer, is shown in Figure 2. For this molecular marker, a band of $750 \mathrm{bp}$ was present in the Amarela da Rama Cinza cultivar but absent in the Branca 1, Quarenta Quilos, Guaíra, Amarela de São Domingos, Branca 3, Pão, Amarela 1, and Amarela 2 cultivars. These cultivars were the most divergent shown by molecular analysis (Table 3).

The genetic dissimilarities, which were determined by the arithmetical complement of Jaccard's coefficient, are shown in Table 3. This methodology has been used in several studies on different crops, which are reported in the literature. Costa et al. (2003) used the Jaccard's coefficients to estimate the genetic similarity among sweet cassava cultivars using RAPD molecular markers, and Ceolin et al. (2007) used the Jaccard's coefficient arithmetic complements to measure the genetic dissimilarity in common bean accessions. In the present study, molecular analysis indicated that the cultivars that were the closest genetically were the Guaíra and Quarenta Quilos $\left(d_{i i}=23.38\right)$, the Amarela da Rama Branca and Branca de Maringá $\left(\mathrm{d}_{\mathrm{i}}\right.$, $\left.=26.67\right)$, and the Branca de Maringá and Branca $2\left(d_{i i},=28.24\right)$ cultivars. The most divergent combinations were the Branca 3 and Amarela da Rama Cinza and the Branca 3 and Amarela 2 cultivars, with dissimilarity values of 58.03 and 57.84, respectively.

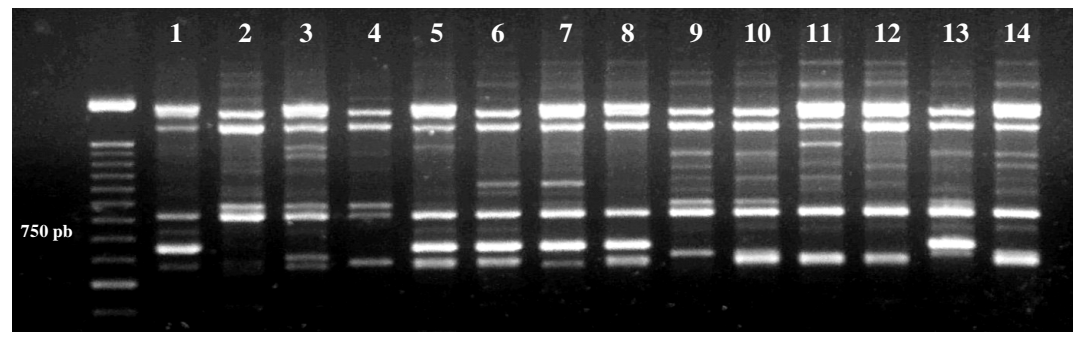

Figure 2 - Photograph illustrating the result of the genomic DNA amplification, using the RAPD OPK 14, for the cultivars: (1) Caipira, (2) Branca 1, (3) Quarenta Quilos, (4) Guaíra, (5) Amarela da Rama Branca, (6) Amarela da Rama Cinza, (7) Branca de Maringá, (8) Branca 2, (9) Amarela de São Domingos, (10) Branca 3, (11) Pão, (12) Amarela 1, (13) Fécula Branca, (14) Amarela 2. 
Table 3 - Jaccard's coefficient (above the diagonal) and its arithmetical complements (below the diagonal), obtained with RAPD molecular markers, among 14 sweet cassava cultivars. Maringá, 2004.

\begin{tabular}{lcccccccccccccccc}
\hline & Caip. & Br.1 & Q.Q. & Gua. & A.R.Br. A.R.C. Br.M. & Br.2 & A.S.D. & Br.3 & Pão & Am.1 & F.Br. & Am.2 \\
\hline Caip. & 0.0 & 0.488 & 0.575 & 0.548 & 0.591 & 0.564 & 0.495 & 0.529 & 0.472 & 0.468 & 0.488 & 0.558 & 0.512 & 0.453 \\
Br.1 & 0.512 & 0.0 & 0.558 & 0.551 & 0.574 & 0.566 & 0.674 & 0.624 & 0.635 & 0.424 & 0.628 & 0.561 & 0.692 & 0.642 \\
Q.Q. & 0.425 & 0.442 & 0.0 & 0.766 & 0.698 & 0.524 & 0.614 & 0.563 & 0.575 & 0.545 & 0.524 & 0.556 & 0.585 & 0.506 \\
Gua. & 0.452 & 0.449 & 0.234 & 0.0 & 0.667 & 0.467 & 0.587 & 0.556 & 0.516 & 0.482 & 0.483 & 0.512 & 0.506 & 0.467 \\
A.R.Br. & 0.409 & 0.426 & 0.302 & 0.333 & 0.0 & 0.527 & 0.733 & 0.648 & 0.624 & 0.511 & 0.616 & 0.556 & 0.636 & 0.543 \\
A.R.C. & 0.436 & 0.434 & 0.476 & 0.533 & 0.473 & 0.0 & 0.568 & 0.553 & 0.602 & 0.420 & 0.571 & 0.627 & 0.636 & 0.530 \\
Br.M. & 0.505 & 0.326 & 0.386 & 0.413 & 0.267 & 0.432 & 0.0 & 0.718 & 0.615 & 0.449 & 0.646 & 0.581 & 0.687 & 0.602 \\
Br.2 & 0.471 & 0.376 & 0.437 & 0.444 & 0.352 & 0.447 & 0.282 & 0.0 & 0.621 & 0.482 & 0.633 & 0.585 & 0.654 & 0.570 \\
A.S.D. & 0.528 & 0.365 & 0.425 & 0.484 & 0.376 & 0.398 & 0.385 & 0.379 & 0.0 & 0.459 & 0.605 & 0.578 & 0.627 & 0.600 \\
Br.3 & 0.532 & 0.576 & 0.455 & 0.518 & 0.489 & 0.580 & 0.551 & 0.518 & 0.541 & 0.0 & 0.455 & 0.468 & 0.481 & 0.422 \\
Pão & 0.513 & 0.372 & 0.476 & 0.517 & 0.384 & 0.429 & 0.354 & 0.367 & 0.395 & 0.545 & 0.0 & 0.566 & 0.662 & 0.653 \\
Am.1 & 0.442 & 0.439 & 0.444 & 0.488 & 0.444 & 0.373 & 0.419 & 0.415 & 0.422 & 0.532 & 0.434 & 0.0 & 0.653 & 0.603 \\
F.Br. & 0.488 & 0.308 & 0.415 & 0.494 & 0.364 & 0.364 & 0.313 & 0.346 & 0.373 & 0.519 & 0.338 & 0.347 & 0.0 & 0.593 \\
Am.2 & 0.547 & 0.358 & 0.494 & 0.533 & 0.457 & 0.470 & 0.398 & 0.430 & 0.400 & 0.578 & 0.347 & 0.397 & 0.407 & 0.0
\end{tabular}

(Caip.) Caipira, (Br.1) Branca 1, (Q.Q.) Quarenta Quilos, (Gua.) Guaíra, (A.R.Br.) Amarela da Rama Branca, (A.R.C.) Amarela da Rama Cinza, (Br.M.) Branca de Maringá, (Br.2) Branca 2, (A.S.D.) Amarela de São Domingos, (Br.3) Branca 3, (Pão) Pão, (Am.1) Amarela 1, (F.Br.) Fécula Branca, (Am.2) Amarela 2.

The dendrogram obtained by applying the nearest neighbor analysis method is shown in Figure 3. This analysis divided the cultivars into four main groups. Group 1, which consisted of the Caipira and Branca 3 cultivars, was the most dissimilar $\left(\mathrm{d}_{\mathrm{ii}}=53.24\right)$ from the others. Group II consisted of the Guaíra, Quarenta Quilos and Amarela da Rama Branca cultivars, and, within this group, the first two were the most dissimilar $\left(\mathrm{d}_{\mathrm{ii}}=23.37\right)$. Group III, which was formed by the Branca 2 and Branca de Maringá cultivars, presented small genetic distances $\left(d_{i i},=28.23\right)$ and had the most similarities between group members compared with to the other cultivars. Group IV consisted of the Pão, Amarela 2, Branca 1, Amarela de São Domingos, Fécula Branca, Amarela da Rama Cinza, and Amarela 1 cultivars. Within this group, the genetic proximity between the Pão and Amarela 2 cultivars $\left(d_{i i},=34.66\right)$, and between the Amarela da Rama Cinza and Amarela 1 cultivars $\left(d_{i i}=37.33\right)$ was highlighted.

The ability of morpho agronomic traits to illustrate genetic divergence has previously been reported in sweet cassava (Gonçalves-Vidigal et al., 1997; Chavarriaga-Aguirre et al., 1999; Colombo et al., 2000; Carvalho and Schaal, 2001; Zacharias et al., 2004; Kizito et al., 2007; Peroni et al., 2007; Siqueira et al., 2009) in the common bean (Phaseolus vulgaris) (Ceolin et al., 2007), in wheat (Triticum aestivum) (Iqbal et al., 2007), in pigeon pea (Cajanus cajan) (Choudhury et al., 2008), and in yam (Dioscorea spp.) (Zannou et al., 2009). 


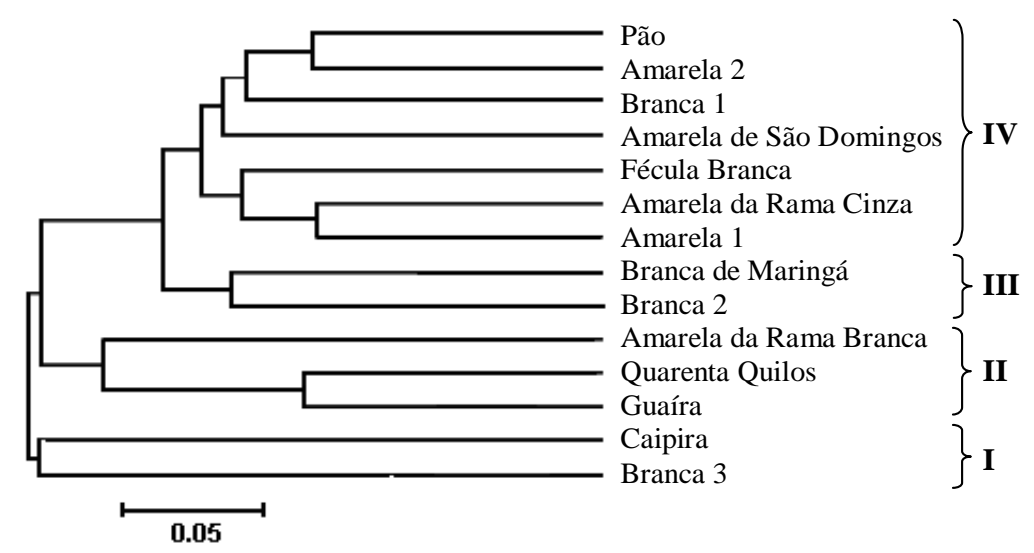

Figure 3 - Dendrogram representative of the genetic divergence among 14 sweet cassava cultivars, obtained by the nearest neighbor analysis method.

This study suggested that a wide range of genetic diversity existed within the sweet cassava germplasm from Paraná state and that this diversity could be useful in the breeding programs. In addition to previous suggestions by Fontes et al. (2002) and Costa et al. (2003) that the genetic distance between the parent cultivars in breeding programs should be high, favorable agronomic traits should be present in at least one, if not both, parents. The data indicates that the Branca 3 cultivar should be crossed with the Pão, Amarela 1, Fécula Branca, and Amarela 2 cultivars for several reasons: a) the high genetic divergence observed between these cultivars, c) the presence of favorable agronomic and culinary characteristics within at least one potential parent, and c) disease resistance on the part of at least one potential parents.

An isolated case that needed great attention from the sweet cassava breeders was the cross between the Branca 3 and Amarela 2 cultivars. This hybridization could be a promising option for the breeder due to the high genetic divergence between these two cultivars, the associated resistance to cassava bacterial blight and superelongation, the low cyanide content, and the shorter cooking time for the tuberous root of the Amarela 2 cultivar (Rimoldi et al., 2006). Although there was high genetic divergence between the Branca 3 and Amarela da Rama Cinza cultivars, they would not be as likely to represent good parents for hybridization, since both of the cultivars were highly susceptible to cassava bacterial blight (Rimoldi et al., 2006).
Since the results that were obtained by the analysis of the morphological agronomic traits were partially similar to those obtained by analysis of the molecular markers, it could be strongly suggested that these results be considered together. When taking into account the genetic divergence results that were estimated by the morphological agronomic traits and by the molecular analyses, the disease resistance/susceptibility of each cultivar, and the agronomic and culinary characteristics of each of the sweet cassava cultivars (Rimoldi et al., 2006), several hybridization options could be suggested from among the more divergent cultivars in order to establish base populations for clone selection. The fact that sweet cassava could be vegetatively propagated means that all heterogenic effects would be apparent in the $F_{1}$ population, which would greatly facilitate the sweet cassava genetic breeding process.

Overall, the following crosses represented the most promise: the Branca 3 with the Caipira, Branca 1, or Amarela 1 cultivars; the Pão with the Caipira, Branca 1, Guaíra, Branca de Maringá, Branca 2, Amarela de São Domingos, or Branca 3 cultivars; the Fécula Branca with the Amarela da Rama Branca, Amarela da Rama Cinza, Amarela 1, Branca 3, and Pão cultivars; and the Amarela 2 with the Caipira, Quarenta Quilos, Guaíra, Branca 3 or Fécula Branca cultivars. Although the Branca 3 cultivar also showed high genetic divergence with the Guaíra, Amarela da Rama Branca, Branca de Maringá, Branca 2, and Amarela de São Domingos cultivars, the susceptibility of all of 
these cultivars to cassava bacterial blight contraindicated their utility for crosshybridization.

\section{CONCLUSIONS}

- The Mahalanobis generalized distance indicated that the most dissimilar pairs of cultivars were the Pão and Guaíra, the Fécula Branca and Pão, and the Pão and Caipira, whereas the most similar were the Fécula Branca and Branca 1, the Branca 3 and Branca 1, and the Guaíra and Branca 1 ;

- The Jaccard's coefficients indicated that the most similar cultivars were the Guaíra and Quarenta Quilos, whereas the most dissimilar were the Branca 3 and Amarela da Rama Cinza;

- The results that were obtained from the agronomic and morphological traits partially agreed with those obtained by the RAPD markers;

- $\quad$ Taken together, these data indicated that promising crosses could be made between the Branca 3 cultivar and the Pão, Amarela 1, Fécula Branca, or Amarela 2 cultivars, because of the high genetic divergence observed between the Branca 3 and these cultivars, their favorable agronomic and culinary characteristics, and the disease resistance on the part of at least one parent that would be involved in the cross.

\section{ACKNOWLEDGMENTS}

The authors thank the Araucária Foundation, Capes, CNPq and the professors, undergraduates, graduates and staff of the Universidade Estadual de Maringá whose help was essential in carrying out this study.

\section{RESUMO}

A divergência genética entre 14 cultivares de mandioca-de-mesa foi estimada mediante o uso de caracteres morfoagronômicos e de marcadores moleculares RAPD. As análises de agrupamento de Tocher e do Vizinho Mais Próximo foram efetuadas. As cultivares mais divergentes foram Pão e Guaíra, Fécula Branca e Pão, e Pão e Caipira, enquanto as mais similares foram Fécula Branca e Branca 1, Branca 3 e Branca 1, e Guaíra e Branca 1. O coeficiente de Jaccard indicou que as cultivares mais similares foram Guaíra e Quarenta Quilos, enquanto as mais dissimilares foram Branca 3 e Amarela da Rama Cinza. A análise de divergência indicou que cruzamentos promissores deveriam ser efetuados entre as cultivares Branca 3, Pão, Amarela 1, Fécula Branca e Amarela 2 pela alta divergência genética, características agronômicas e culinárias favoráveis, e resistência à doenças de parte de pelo menos um dos parentais envolvidos no cruzamento.

\section{REFERENCES}

Allen, A. C. (1994), The origin of Manihot esculenta Crantz (Euphorbiaceae). Genet. Resour. Crop Evol., 41, 133-150

Carvalho, L. J. C. B.; Schaal, B. A. (2001), Assessing genetic diversity in the cassava (Manihot esculenta, Crantz) germplasm collection in Brazil using PCRbased markers. Euphytica, 120, 133-142.

Ceolin, A. C. G.; Gonçalves-Vidigal, M. C.; Vidigal Filho, P. S.; Kvitschal, M. V.; Gonela, A.; Scapim, C. A. (2007), Genetic divergence of Phaseolus vulgaris L. using morpho-agronomic traits by multivariate analysis. Hereditas, 144, 1-9.

Chavarriaga-Aguirre, P.; Maya, M. M.; Tohme, J.; Duque, M. C.; Iglesias, C.; Bonierbale, M. W.; Kresovich, S.; Kochert G. (1999), Using microsatellites, isozymes and AFLPs to evaluate genetic diversity and redundancy in the cassava core collection and to assess the usefulness of DNA-based markers to maintain germplasm collections. Mol. Breed., 5, 263-273.

Choudhury, P. R.; Singh, I. P.; George, B.; Verma, A. K.; Singh N. P. (2008), Assessment of genetic diversity of pigeonpea cultivars using RAPD analysis. Biol. Plant., 52(4), 648-653.

Coimbra, J. L. M.; Guidolin, A. F.; Carvalho, F. I. F. (1998), Coeficientes de trilha, correlações canônicas e divergência genética entre caracteres primários e secundários do rendimento de grãos em genótipos de feijão preto (Phaseolus vulgaris, L.). Pesqui. Agropecu. Gauc., 4, 189-194.

Collard, B. C. Y.; Jahufer, M. Z .Z.; Brouwer, J. B.; Pang, E. C. K. (2005), An introduction to markers, quantitative trait loci (QTL) mapping and markerassisted selection for crop improvement: The basic concepts. Euphytica, 142, 169-196.

Colombo, C.; Second, G.; Charrier, A. (2000), Diversity within American cassava germplasm based on RAPD markers. Genet. Mol. Biol., 23, 189-199. 
Costa, M. R.; Cardoso, E. R.; Ohaze, M. M. M. (2003), Similaridade genética de cultivares de mandioca (Manihot esculenta, Crantz) por meio de marcadores RAPD. Ciênc. Agrotec., 27, 158-164.

Cruz, C.D. (2006), Programa Genes: versão Windows; aplicativo computacional em genética e estatística. UFV, Viçosa, pp. 648.

Cruz, C. D.; Carneiro, P. C. S. (2006), Modelos biométricos aplicados ao melhoramento genético, 2.ed. rev., UFV - Imprensa Universitária, Viçosa, pp. 585.

Doyle, J. J.; Doyle, J. L. (1990), Isolation of plant DNA from fresh tissues. Focus, 27, 13-15.

Emperaire, L.; Peroni, N. (2007), Traditional management of agrobiodiversity in Brazil: a case study of manioc. Hum. Ecol., 35, 761-768.

Farias, F. J. C.; Ramalho, M. A. P.; Carvalho, L. P.; Moreira, J. A. N.; Costa, J. N. (1997), Parâmetros de estabilidade propostos por Lin e Binns (1988) comparados com o método da regressão. Pesqui. Agropecu. Bras., 32, 407-414.

Fontes, J. R. M.; Sakiyama, N. S.; Cardoso, A. A.; Zambolim, L.; Pereira, A. A. (2002), Avaliação de híbridos $\mathrm{F}_{1}$ de café (Coffea arábica, L.) e respectivos progenitores com marcadores RAPD. Ceres, 49, 283294.

Fukuda, W. M. G.; Guevara, C. L. (1998), Descritores morfológicos e agronômicos para a caracterização de mandioca (Manihot esculenta Crantz). Documentos 78. Embrapa-CNPMF: Cruz das Almas.

Gonçalves-Vidigal, M. C.; Vidigal Filho, P. S.; Amaral Júnior, A. T.; Braccini, A. L. (1997), Divergência genética entre cultivares de mandioca por meio de estatística multivariada. Bragantia, 56(2), 263-271.

Grosmann, J.; Freitas, A. G. (1950), Determinação do teor de matéria seca pelo peso específico em raízes de mandioca. Rev. Agropecu., 14, 75-80.

Iqbal, A.; Khan, A. S.; Khan, I. A.; Awan, F. S.; Ahmad, A.; Khan A. A. (2007), Study of genetic divergence among wheat genotypes through random amplified polymorphic DNA. Genet. Mol. Res., 3(6), 476-481.

Kizito, E. B.; Chiwona-Karltun, L.; Egwang, T.; Fregene, M.; Westerbergh, A. (2007), Genetic diversity and variety composition of cassava on small-scale farms in Uganda: an interdisciplinary study using genetic markers and farmer interviews. Genetics, 130, 301-318.

Kvitschal, M. V.; Vidigal Filho, P. S.; Scapim, C. A.; Gonçalves-Vidigal, M. C.; Sagrilo, E.; Pequeno, M. G.; Rimoldi, F. (2009), Comparison of methods for phenotypic stability analysis of cassava (Manihot esculenta Crantz) genotypes for yield and storage root dry matter content. Braz. Arch. Biol. Technol., 52(1), 163-175.
Mattson (1946), The cook ability of yellow peas. Acta Agric. Suec., 1, 185-190.

Peroni, N.; Kageyama, P. Y.; Begossi, A. (2007), Molecular differentiation, diversity, and folk classification of 'sweet' and 'bitter'cassava (Manihot esculenta, Crantz) in Caiçara and Cabloco management systems (Brazil). Genet. Resour. Crop Evol., 54, 1333-1349.

Rimoldi, F.; Vidigal Filho, P. S.; Gonçalves-Vidigal M. C.; Clemente, E.; Pequeno, M. G.; Miranda, L.; Kvitschal, M. V. (2006), Produtividade, composição química e tempo de cozimento de cultivares de mandioca-de-mesa coletadas no Estado do Paraná. Acta Sci. Agron., 1(28), 63-69.

Sagrilo, E.; Vidigal Filho, P. S.; Pequeno, M. G.; Gonçalves-Vidigal, M. C.; Scapim, C. A.; Kvitschal, M. V.; Maia, R. R.; Rimoldi, F. (2006), Effect of harvest period on foliage production and dry matter distribution in five cassava cultivars during the second plant cycle. Braz. Arch. Biol. Technol., 49(6), 1007-1018.

Siqueira, M. V. B. M.; Queiroz-Silva, J. R.; Bressan, E. A.; Borges, A.; Pereira, K. J. C.; Pinto, J. G.; Veasey, E. A. (2009), Genetic characterization of cassava (Manihot esculenta) landraces in Brazil assessed with simple sequence repeats. Genet. Mol. Biol., 32(1), 104-110.

Williams, J. G. K.; Kubelik, A. R.; Livak, K. J.; Rafalski, J. A.; Tingey, S. V. (1990), DNA polymorphism amplified by arbitrary primers are useful as genetic markers. Nucleic Acids Res., 18, 6532-6535.

Zacharias, A. M.; Botha, A. M.; Labuschagne, M. T.; Benesi, I. R. M. (2004), Characterization and genetic distance analysis of cassava (Manihot esculenta Crantz) germplasm from Mozambique using RAPD fingerprint. Euphytica, 138, 49-53.

Zannou, A.; Agbicodo, E.; Zoundjihékpon J.; Struik, A.; Ahanchédé, A.; Kossou, D. K.; Sanni, A. (2009), Genetic variability in yam cultivars from the GuineaSudan zone of Benin assessed by random amplified polymorphic DNA. Afr. J. Biotechnol., 8(1), 26-36.

Received: October 08, 2009; Revised: April 05, 2009; Accepted: September 24, 2010 